\title{
Dialysis water treated by reverse osmosis decreases the levels of C-reactive protein in uremic patients
}

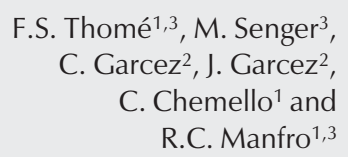

\author{
1 Programa de Pós-Graduação em Ciências Médicas: Nefrologia, \\ 2Departamento de Medicina Interna, Faculdade de Medicina, \\ Universidade Federal do Rio Grande do Sul, Porto Alegre, RS, Brasil \\ ${ }^{3}$ Hospital de Clínicas de Porto Alegre, Porto Alegre, RS, Brasil
}

\section{Correspondence}

F.S. Thomé

R. Ramiro Barcelos, 2350, Sala 2030

90035-003 Porto Alegre, RS

Brasil

Fax: +51-3332-8324

E-mail: fernandosthome@uol.com.br $\ldots \ldots \ldots \ldots \ldots \ldots . . . . . .$.

Received April 5, 2004 Accepted March 2, 2005

\begin{abstract}
Atherosclerosis is a major complication of chronic renal failure. Microinflammation is involved in atherogenesis and is associated with uremia and dialysis. The role of dialysate water contamination in inducing inflammation has been debated. Our aim was to study inflammatory markers in patients on chronic dialysis, before and 3 to 6 months after switching the water purification system from deionization to reverse osmosis. Patients had demographic, clinical and nutritional information collected and blood drawn for determination of albumin, ferritin, C-reactive protein (CRP), interleukin6 , and tumor necrosis factor- $\alpha$ in both situations. Acceptable levels of water purity were less than 200 colony-forming units of bacteria and less than $1 \mathrm{ng} / \mathrm{ml}$ of endotoxin. Sixteen patients died. They had higher median CRP (26.6 vs $11.2 \mathrm{mg} / \mathrm{dl}, \mathrm{P}=0.007)$ and lower median albumin levels ( 3.1 vs $3.9 \mathrm{~g} / \mathrm{l}, \mathrm{P}<0.05)$ compared to the 31 survivors. Eight patients were excluded because of obvious inflammatory conditions. From the 23 remaining patients (mean age \pm SD: $51.3 \pm 13.9$ years), 18 had a decrease in CRP after the water treatment system was changed. Overall, median CRP was lower with reverse osmosis than with deionization (13.2 vs $4.5 \mathrm{mg} / \mathrm{l}, \mathrm{P}=$ $0.022, \mathrm{~N}=23$ ). There was no difference in albumin, cytokines, subjective global evaluation, or clinical and biochemical parameters. In conclusion, uremic patients presented a clinically significant reduction in CRP levels when dialysate water purification system switched from deionization to reverse osmosis. It is possible that better water treatments induce less inflammation and eventually less atherosclerosis in hemodialysis patients.
\end{abstract}

Key words

- Hemodialysis

- C-reactive protein

- Dialysate water

- Reverse osmosis

- Inflammation

- Uremia

....................

\section{Introduction}

Accelerated atherosclerosis in uremic patients on dialysis has been recognized for many years (1) and, despite advances in renal replacement therapies, it remains an impor- tant cause of elevated morbidity and mortality $(2,3)$. This is only partially explained by traditional risk factors of vascular disease such as dyslipidemia and hypertension, among others. Factors like hyperhomocystinemia, oxidative stress and a microinflammatory 
state have been more recently recognized $(4,5)$, and chronic renal insufficiency has been shown to be an independent risk factor associated with atherosclerosis (6). A step forward in understanding this problem was the recognition of the relationship between malnutrition, chronic inflammation and atherosclerosis, the so-called MIA syndrome $(7,8)$. In fact, there are several reasons to explain a persistent microinflammatory state in uremic patients, including the extracorporeal circulation using bioincompatible foreign materials, contact of blood with endotoxins from the dialysate water, frequent infections, and probably the uremic state itself. This condition may be recognized by induction of cytokines and elevation of acute phase reaction proteins like C-reactive protein (CRP) (9). This protein has been consistently associated with cardiovascular mortality in dialysis patients and is considered to be the best marker of inflammation in uremic subjects (10-13).

In Brazil, water used in hemodialysis is purified basically by two methods, i.e., deionization and reverse osmosis (14). The aim of the present study was to prospectively evaluate the inflammatory activity of uremic patients on hemodialysis in a unit where the water purification system was changed from deionization to reverse osmosis.

\section{Patients and Methods}

A hemodialysis unit of a general tertiary care hospital in Porto Alegre, RS, Brazil, was prospectively studied as it changed its dialysis water purification system. Water was collected from two points in the distribution loop, one just before the last dialysis equipment and another randomly selected and also from the filter reprocessing bench, monthly for 3 months before the change of the deionization system and for 4 months after the implementation of the reverse osmosis system. Standard cultures for heterotrophic bacteria and coliforms were performed.
Detection of endotoxin and semi-quantitative analysis were performed by the Limulus amebocyte lysate test (15). Deionization included a sand column, an activated charcoal column, and two resin columns, an anionic one and a cationic one (Permution System, Curitiba, PR, Brazil). A micropore filter was included before the distribution circuit and was changed weekly. This equipment allowed a water quality consistently in accordance with the Brazilian regulations for hemodialysis, i.e., less than 200 colony-forming units (CFU) and less than $1.0 \mathrm{ng} / \mathrm{ml}$ endotoxin. The new replacement system included a sand column, an activated charcoal column, a softener and a reverse osmosis system (Osmonics, Minnetonka, MN, USA).

Forty-seven patients on regular hemodialysis for at least 3 months, all dialyzed with a cellulose tri-acetate membrane, representing $94 \%$ of the total patients of the unit, were studied before the water system change. Eight patients were excluded because of obvious inflammatory activity either at the initial or at the final evaluation. Reasons for exclusion were having a central venous catheter, urinary tract infections, respiratory infections, infected skin ulcers, and colecystitis. Sixteen patients eventually died for several reasons and were also excluded. Three to 6 months after the change in the purification system, 23 patients were reevaluated. Demographic, clinical and laboratory data and the water parameters were recorded on both occasions. Nutritional evaluation was also performed using subjective global assessment (SGA) (16-18). Blood was collected from each patient before a hemodialysis session for serum albumin, CRP, interleukin6 (IL-6), and tumor necrosis factor-alpha (TNF- $\alpha$ ) determination. High sensitivity CRP was determined by nephelometry and the cytokines were determined by ELISA (R\&D Systems, Inc., Minneapolis, MN, USA).

Results are reported as means \pm SD or medians and range. Changes in parameters 
were compared by a paired $t$-test for normal distribution variables or by the Wilcoxon test for CRP and cytokines. Comparisons of independent parameters in the initial or the final evaluation were analyzed by an unpaired $t$-test or by the Mann-Whitney test. Pearson's correlation coefficient was used to analyze the association between variables. The level of significance was set at $\mathrm{P}<0.05$ for all analyses.

\section{Results}

Twenty water samples were analyzed, nine treated by deionization and eleven by reverse osmosis (one sample was lost). All results were within the limits determined by Brazilian regulations and the Association for the Advancement of Medical Instrumentation standards. Bacteriologic investigation showed 4 samples of deionized water with less than $1 \mathrm{CFU} / \mathrm{ml}$ and 5 with 10 to $185 \mathrm{CFU} /$ $\mathrm{ml}$, while 8 samples of the water treated with reverse osmosis had less than $1 \mathrm{CFU} / \mathrm{ml}$ and three had 6 to $120 \mathrm{CFU} / \mathrm{ml}$. The levels of endotoxin were less than $0.03 \mathrm{ng} / \mathrm{ml}$ in 5 samples of deionized water, and 0.03 to 1.0 $\mathrm{ng} / \mathrm{ml}$ in 4 samples, while all 11 samples of water treated with reverse osmosis had less than $0.03 \mathrm{ng} / \mathrm{ml}$.

Forty-seven patients were initially evaluated. There were 30 men (64\%), mean age was $58.7 \pm 15.8$ years, $33 \%$ were diabetic and $77 \%$ were hypertensive. Sixteen patients died during the initial part of the study. When compared to the survivors, they had higher CRP levels (26.6 vs $11.2 \mathrm{mg} / \mathrm{l}, \mathrm{P}=0.007)$ and lower albumin levels $(3.1 \pm 0.6$ vs $3.9 \pm 0.3$ $\mathrm{g} / \mathrm{l}, \mathrm{P}<0.05)$.

Twenty-three patients had no obvious inflammatory conditions and were comparable before and after the change in the water purification system. Clinical information regarding these patients is shown in Table 1. There were 16 men (70\%) (mean age: 51.3 \pm 13.9 years), $26 \%$ had diabetes mellitus and $74 \%$ high blood pressure. They had been on dialysis for $45.3 \pm 38.4$ months

Results are presented in Table 2. There was no difference in SGA, albumin, cytokines, or other biochemical data related to dialysis adequacy. Median CRP was significantly lower after the change (13.2 vs 4.5 $\mathrm{mg} / \mathrm{l}, \mathrm{P}=0.022$ ). Eighteen of the 23 patients had a reduction in CRP levels. Of the 18

Table 1. Characteristics of patients evaluated before and after the change from deionization to reverse osmosis for the purification of dialysis water.

\begin{tabular}{lc}
\hline Parameter & $\begin{array}{c}\text { Number of patients } \\
(\%)\end{array}$ \\
\hline Number & 23 \\
Males & $16(70 \%)$ \\
Diabetics & $6(26 \%)$ \\
Hypertensives & $17(74 \%)$ \\
Current or past smokers & $4(18 \%)$ \\
African origin & $6(26 \%)$ \\
Ischemic cardiopathy & $3(13 \%)$ \\
Chronic pulmonary disease & $3(13 \%)$ \\
Peripheral vascular disease & $5(22 \%)$ \\
Cerebrovascular disease & $1(4 \%)$ \\
Anti-HCV positive & $6(26 \%)$ \\
Peptic disease & $2(9 \%)$ \\
BMl $>25$ kg/m² & $10(43 \%)$ \\
BMl <20 kg/m² & $0(0 \%)$ \\
Light/moderate malnutrition & $5(22 \%)$ \\
Severe malnutrition & $1(4 \%)$ \\
&
\end{tabular}

Data are reported as number of patients with percent in parentheses. Anti-HCV = antibodies to hepatitis $\mathrm{C}$ virus; $\mathrm{BMI}=$ body mass index.

Table 2. Inflammatory activity in patients on hemodialysis with deionized water and after a change to reverse osmosis.

\begin{tabular}{lcc}
\hline Parameter & Deionized water & Reverse osmosis water \\
\hline C-reactive protein $(\mathrm{mg} / \mathrm{l})$ & $13.7 \pm 9.6(13.2)$ & $9.6 \pm 12.1(4.5)^{*}$ \\
Interleukin-6 $(\mathrm{pg} / \mathrm{ml})$ & $4.8 \pm 5.9(3.4)$ & $4.6 \pm 7.3(1.9)$ \\
Tumor necrosis factor- $\alpha(\mathrm{pg} / \mathrm{ml})$ & $11.2 \pm 0.9(10.3)$ & $11.1 \pm 0.9(10.1)$ \\
Albumin $(\mathrm{g} / \mathrm{l})$ & $3.6 \pm 0.6$ & $3.9 \pm 0.3$ \\
Ferritin $(\mathrm{ng} / \mathrm{ml})$ & $460.2 \pm 420.9$ & $531.1 \pm 261.7$ \\
Kt/V & $1.17 \pm 0.4$ & $1.2 \pm 0.4$ \\
SGA (range 7-35) & $11.9 \pm 4.1(11.0)$ & $10.5 \pm 3.9(10.1)$
\end{tabular}

Data are reported as means $\pm \mathrm{SD}$ (median in parentheses). $\mathrm{Kt} / \mathrm{V}=$ fractional clearance of urea (amount of plasma cleared of urea divided by the urea distribution volume); $\mathrm{SGA}=$ subjective global assessment.

${ }^{*} \mathrm{P}=0.022$ compared to deionized water (Wilcoxon test). 
patients with an initial CRP higher than $6 \mathrm{mg} /$ 1, $9(50 \%)$ had CRP $<6 \mathrm{mg} / 1$ in the final measurement. Figure 1 shows the variation in CRP levels before and after the change of the water treatment system. In a regression model, the final levels of CRP were negatively associated with the final levels of albumin (correlation coefficient, $-0.357, \mathrm{P}=$ 0.007 ) and positively associated with the initial levels of CRP (correlation coefficient, $0.673, \mathrm{P}<0.001)$.

There was a positive correlation between CRP and ferritin (Pearson's correlation coefficient $=0.382, \mathrm{P}=0.008)$, but not between CRP or ferritin and albumin. Patients excluded because of obvious inflammatory conditions $(\mathrm{N}=8)$ had higher IL-6 levels than those who did not present clinical conditions or events associated with inflammation $(11.3$ \pm 12.4 vs $4.8 \pm 5.9 \mathrm{pg} / \mathrm{ml}, \mathrm{P}=0.054)$. Patients excluded because of central venous catheters $(\mathrm{N}=6)$ had higher CRP levels than those with an arteriovenous fistula $(\mathrm{N}=41$; $50.0 \pm 42.4$ vs $18.8 \pm 18.5 \mathrm{mg} / \mathrm{l}, \mathrm{P}=0.056)$. On the other hand, current $(\mathrm{N}=6)$ or past smokers $(\mathrm{N}=19)$ had higher CRP levels than those who never smoked $(\mathrm{N}=22 ; 37.1 \mathrm{vs}$

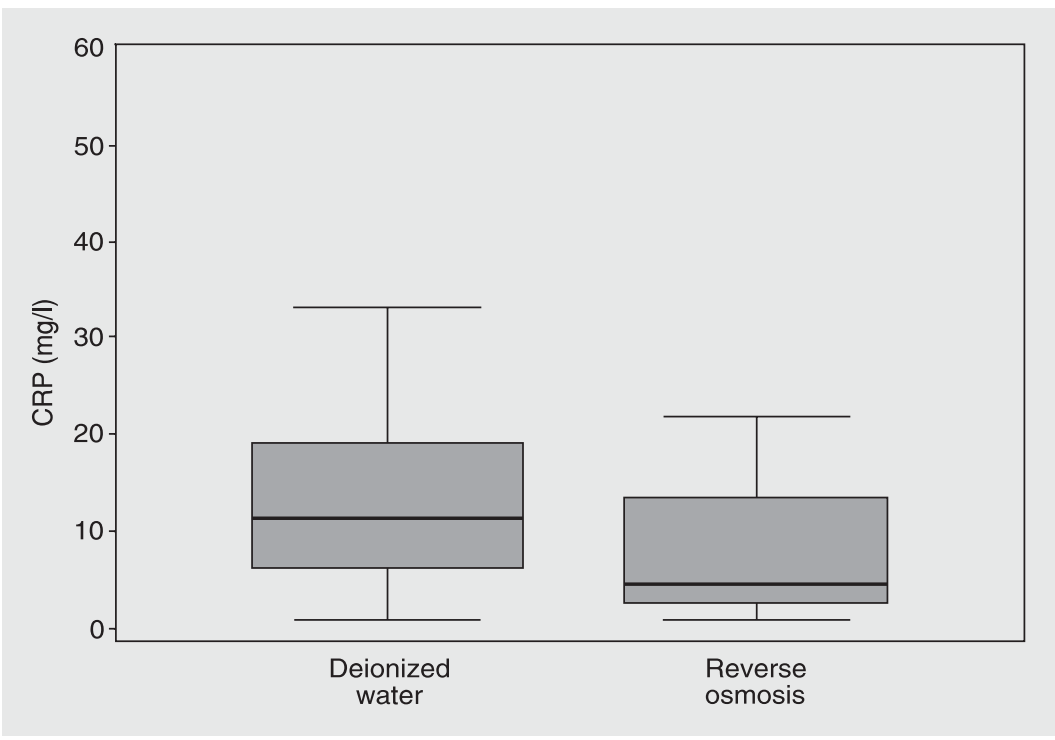

Figure 1. C-reactive protein (CRP) levels in patients $(N=23)$ submitted to dialysis with deionized water and then switched to dialysis with reverse osmosis-treated water. The thick lines show the medians: 13.2 vs $4.5 \mathrm{mg} / \mathrm{l}, \mathrm{P}=0.022$; Wilcoxon test. Boxes indicate quartiles, and thin lines show ranges.
$18.9 \mathrm{mg} / \mathrm{l}, \mathrm{P}<0.05)$. There was no difference in CRP, IL-6 or TNF- $\alpha$ relative to gender, age, anti-HCV antibody state, diabetes, race, basic renal disease, hypertension, or nutritional status determined by SGA.

\section{Discussion}

The present study confirms previous observations that uremic patients on hemodialysis have increased inflammatory activity defined by increased CRP or cytokines (IL6 , TNF- $\alpha$ ) (19-23). Our unselected patient population presented high morbidity compatible with the situation observed in a general hospital. Accordingly, there was a tendency towards referring the sickest and oldest patients to our hemodialysis unit, as opposed to units from other affiliated hospitals, a fact that could explain the higher than average mortality rate. Patients with obvious clinical inflammation or with temporary vascular catheters presented high CRP levels, demonstrating that uremic patients may show persistent inflammatory activity for multiple reasons. Although this was not a cohort study aiming to evaluate prognostic factors, the finding of increased CRP in patients who eventually died supports previous studies that demonstrated the prognostic power of inflammation markers $(24,25)$. Nevertheless, the albumin levels or nutritional evaluation of patients with higher inflammatory activity did not differ from those observed in the others. This is possibly too gross an evaluation for such a small number of patients to reveal an association. However, serum ferritin was clearly correlated with CRP. Smokers presented elevated CRP levels, and it has been demonstrated that both smoking and inflammation are related to increased oxidative stress (26).

Our main result shows a fall in median CRP from 13.2 to $4.5 \mathrm{mg} / \mathrm{l}(\mathrm{P}<0.05)$. In agreement with previous studies, this suggests that hemodialysis water, even with acceptable levels of bacterial contamination, 
is capable of inducing inflammatory activity $(27,28)$, although this subject is still being debated (29,30). Schiffl and colleagues (31) demonstrated that the use of ultrapure water leads to the improvement of inflammatory and nutritional parameters. In their study, the nutritional benefit to patients just starting dialysis was evident when they were submitted to various anthropometric measurements. Our patients showed a significant reduction in CRP after a few months of treatment with reverse osmosis-purified water. This water could not be considered ultrapure because three samples had more than $1 \mathrm{CFU} / \mathrm{ml}$, but seemed much purer than the previous deionized water. It is important to notice that both deionization and reverse osmosis were efficient in producing water compatible with Brazilian and international standards. Today, about $10 \%$ of the hemodialysis units in Brazil do not use reverse osmosis for water purification (14). Inadequate water treatment may lead to complications such as pyrogen reaction outbreaks and fatal contamination with cyanobacteria (32).

We did not observe changes in IL- 6 or TNF- $\alpha$ levels, probably because these cytokines tend to show a brief elevation after induction by an inflammatory stimulus, while CRP better represents a chronic inflammatory state (13). In addition, TNF- $\alpha$ levels were not very high even in the patients with other signs of inflammation, as also reported by others $(33,34)$. It is interesting to note that CRP levels after the change of the water purification system correlated closely with the previous CRP levels, suggesting that the patients present a pattern of inflammatory activity dependent on other factors. This fact has been emphasized before, making this protein useful as a prognostic tool, even after single isolated measurements $(24,25,35,36)$, despite a high intra-individual variation (37).

In conclusion, in a natural experiment based on the change of the water purification system in a hemodialysis unit treating unselected patients, we demonstrated that: a) patients who eventually died had higher inflammatory activity than the survivors; b) the survivors, without obvious clinical inflammation, when dialyzing with another water purification system, apparently with lower levels of endotoxin, presented a significant and clinically relevant reduction of CRP levels. This occurred even though both water treatments presented acceptable levels of bacterial contamination and endotoxin. Although several causes contribute to the chronic microinflammatory state of uremic patients on dialysis, a small contamination of dialysate water with bacterial endotoxin may be an important factor to be considered, specially in developing countries, where cost restrictions may lead to the use of less efficient water purification systems.

\section{References}

1. Lindner A, Charra B, Sherrard DJ \& Scribner BH (1974). Accelerated atherosclerosis in prolonged maintenance hemodialysis. New England Journal of Medicine, 290: 697-701.

2. Goodman WG, Goldin J, Kuizon BD et al. (2000). Coronary artery calcification in young adults with end-stage renal disease who are undergoing dialysis. New England Journal of Medicine, 342: 14781483.

3. United States Renal Data Systems, USRDS (2003). Annual Data Report: Atlas of End-Stage Renal Disease in the United States, National Institutes of Health, National Institute of Diabetes and Digestive and Kidney Diseases, Bethesda, MD, 2003. http// www.usrds.org/adr.htm. Accessed August 2003.

4. Yaqoob MM (2002). Emerging cardiovascular risk factors in end- stage renal disease. Journal of Nephrology, 15: 205-208.

5. Rattazzi M, Puato M, Faggin E, Bertipaglia B, Grego F \& Pauletto $P$ (2003). New markers of accelerated atherosclerosis in endstage renal disease. Journal of Nephrology, 16: 11-20.

6. Henry RM, Kostense PJ, Bos G, Dekker JM, Nijpels G, Heine RJ, Bouter LM \& Stehouwer CD (2002). Mild renal insufficiency is associated with increased cardiovascular mortality: The Hoorn Study. Kidney International, 62: 1402-1407.

7. Stenvinkel $P$, Heimbürger $O$, Lindholm B, Kaysen GA \& Bergstrom $J(2000)$. Are there two types of malnutrition in chronic renal failure? Evidence for relationships between malnutrition, inflammation and atherosclerosis (MIA syndrome). Nephrology, Dialysis, Transplantation, 15: 953-960. 
8. Stenvinkel $P$ (2002). The malnutrition, inflammation, and atherosclerosis (MIA) syndrome - the heart of the matter. Nephrology, Dialysis, Transplantation, 17 (Suppl 11): 28-31.

9. McIntyre C, Harper I, MacDougall C, Raine AE, Williams A \& Baker LR (1997). Serum C-reactive protein as marker for infection and inflammation in regular dialysis patients. Clinical Nephrology, 48: 371-374.

10. Arici M \& Walls $J$ (2001). End-stage renal disease, atherosclerosis, and mortality: is C-reactive protein the missing link? Kidney International, 59: 407-414.

11. Wanner C, Zimmermann J, Schwedler S \& Metzger T (2002). Inflammation and cardiovascular risk in dialysis patients. Kidney International, 61: S99-S102.

12. Koenig W (2003). Update on C-reactive protein as risk marker in cardiovascular disease. Kidney International, 63: 58-61.

13. Kaysen GA (2002). Role of inflammation and its treatment in ESRD patients. Blood Purification, 20: 70-80.

14. Sociedade Brasileira de Nefrologia. Censo - Dezembro, 2002. http//www.sbn.org.br. Accessed May 2003.

15. Prior R (1990). The LAL test. In: Clinical Applications of the Limulus Amebocyte Lysate Test. CRC Press, Boston, MA, USA, 27-36.

16. Detsky AS, McLaughlin JR, Baker JP, Johnston N, Whittaker S, Mendelson RA \& Jeejeebhoy KN (1987). What is subjective global assessment of nutritional status? Journal of Parenteral and Enteral Nutrition, 11: 8-13.

17. Martins C (2001). Protocolo de Procedimentos Nutricionais. In: Riella MC \& Martins C (Editors), Nutrição e o Rim. Guanabara Koogan S.A., Rio de Janeiro, RJ, Brazil, 311-344.

18. Kalantar-Zadeh K, Kleiner M, Dunne E, Lee GH \& Luft FC (1999). A modified quantitative subjective global assessment of nutrition for dialysis patients. Nephrology, Dialysis, Transplantation, 14: 1732-1738.

19. Haubitz M, Brunkhorst R, Wrenger E, Froese P, Schulze M \& Koch K (1996). Chronic induction of C-reactive protein by hemodialysis, but not by peritoneal dialysis therapy. Peritoneal Dialysis International, 16: 158-162.

20. Cavaillon JM, Poignet JL, Fitting C \& Delons S (1992). Serum interleukin-6 in long-term hemodialyzed patients. Nephron, 60: 307-313.

21. Pertosa G, Grandaliano G, Gesualdo L \& Schena FP (2000). Clinical relevance of cytokine production in hemodialysis. Kidney International, 76: S104-S111.

22. Kunitoshi I, Tozawa M, Yoshi S \& Fukiyama K (1999). Serum Creactive protein (CRP) and risk of death in chronic dialysis patients. Nephrology, Dialysis, Transplantation, 14: 1956-1960.

23. Tetta C, David S, Mariano F, De Nitti C \& Panichi V (2001). Alterations of the cytokine network in hemodialysis. Journal of Nephrology, 14: s22-s29.

24. Wang AY, Woo J, Lam CW, Wang M, Sea MM, Lui SF, Li PK \&
Sanderson J (2003). Is a single time point C-reactive protein predictive of outcome in peritoneal dialysis patients? Journal of the American Society of Nephrology, 14: 1871-1879.

25. Yeun JY, Levine RA, Mantadilok V \& Kaysen GA (2000). Creactive protein predicts all-cause and cardiovascular mortality in hemodialysis patients. American Journal of Kidney Diseases, 35: 469-476.

26. Block G, Dietrich M, Norkus EP, Morrow JD, Hudes M, Caan B \& Packer $L$ (2002). Factors associated with oxidative stress in human populations. American Journal of Epidemiology, 156: 274285.

27. Lonnemann $G$ (2000). Chronic inflammation in hemodialysis: the role of contaminated dialysate. Blood Purification, 18: 214-223.

28. Canaud B, Bosc JY, Leray H, Morena M \& Stec F (2000). Microbiologic purity of dialysate: rationale and technical aspects. Blood Purification, 18: 200-213.

29. Nubé MJ \& Grooteman MP (2001). Impact of contaminated dialysate on long-term haemodialysis-related complications: is it really that important? Nephrology, Dialysis, Transplantation, 16: 19861991.

30. Tetta C, Panichi V, Wratten ML, Palla R \& Lonneman G (1998). Plasma C-reactive protein is linked to backfiltration-associated interleukin-6 production. 44th Annual ASAIO Conference Abstract, New York, April 1998. American Society for Artificial Internal Organs Journal, 67A: 44.

31. Schiffl H, Lang SM, Stratakis D \& Fischer R (2001). Effects of ultrapure dialysis fluid on nutritional status and inflammatory parameters. Nephrology, Dialysis, Transplantation, 16: 1863-1869.

32. Jochimsen EM, Carmichael WW, An JS et al. (1998). Liver failure and death after exposure to microcystins at a hemodialysis center in Brazil. New England Journal of Medicine, 338: 873-878.

33. Tarakcioglu M, Erbagci AB, Usalan C, Deveci $R$ \& Kocabas $R$ (2002). Acute effect of hemodialysis on serum levels of the proinflammatory cytokines. Mediators of Inflammation, 12: 15-19.

34. Malaponte G, Bevelacqua V, Fatuzzo P, Rapisarda F, Emmanuele G, Travali S \& Mazzarino MC (2002). IL-1B, TNF- $\alpha$ and IL-6 release from monocytes in haemodialysis patients in relation to dialytic age. Nephrology, Dialysis, Transplantation, 17: 1964-1970.

35. Kaysen GA (1999). Markers of chronic inflammation in CRF and factors that influence this chronic inflammatory state. Symposium of the American Society of Nephrology Annual Scientific Meeting, Miami, FL, USA, November 1999. http//www.HDCN.com. Accessed December 2002.

36. Bellomo G, Lippi G, Saronio P, Reboldi G, Verdura C, Timio F \& Timio M (2003). Inflammation, infection and cardiovascular events in chronic hemodialysis patients: a prospective study. Journal of Nephrology, 16: 245-251.

37. Boenisch O, Ehmke KD, Heddergott A, Naoum C, Frei U \& Schindler R (2002). C-reactive protein and cytokine plasma levels in hemodialysis patients. Journal of Nephrology, 15: 547-551. 